\title{
Methodological Approaches to Study Internet Financial Communication
}

\author{
Pozniak Laetitia \\ University of Mons, Mons, Belgium
}

\begin{abstract}
The aim of this paper is to show how qualitative and quantitative approaches can be complementary to study internet financial communication in a thesis by papers and how grounded theory (GT) can be the link among the different papers of the thesis. The study context of our thesis was the unregulated markets of New York Stock Exchange (NYSE) Euronext Brussels and the problematic rose from this context: What is the voluntary effort of communication when there is no obligation of internet financial communication? Four papers tried to answer this central question and other following research questions. To answer those research questions, several methodological approaches were used: content analysis of websites and scoring, linear regression, paired sample, and interviews. At the end of our thesis by papers, we discovered that GT was the general methodological travel among the papers: Every article had for vocation to try to answer the questions raised by the previous article.
\end{abstract}

Keywords: quantitative and qualitative approaches, grounded theory (GT), induction, financial communication, internet, unregulated markets

\section{Introduction}

Our Ph.D. research, passed in June 2013, was interested in internet financial communication and especially the case of small- and medium-sized enterprises (SMEs) quoted on unregulated markets of Brussels.

What was the most specific on those markets and at the beginning of our problematic is that there is no obligation of communication. And so, we wondered, "Do listed firms on unregulated markets of Brussels make a voluntary effort of internet financial communication?”. Other research questions followed this starting question.

Our thesis was composed of four papers; each of them used a methodology to answer a specific research question.

This paper aims at showing how qualitative and quantitative approaches can be complementary to study internet financial communication in a thesis by papers and how grounded theory (GT) can be the link among the different papers of the thesis.

This paper is organized as follows: First, we present the context of the study: the unregulated markets of New York Stock Exchange (NYSE) Euronext Brussels and the problematic rose from this context. Then, we expose the different methodological approaches used in our researches: content analysis of websites and scoring, linear regression, paired sample, and interviews. Finally, we demonstrate how GT was the general methodological travel among the papers: Every article had for vocation to try to answer the questions raised by the previous article.

Pozniak Laetitia, Ph.D. student, teaching assistant, Warocqué School of Business and Economics, University of Mons. Email: laetitia.pozniak@umons.ac.be. 


\section{Context of the Study}

Our researches focus on firms quoted on unregulated markets of Brussels and their internet financial communication.

The unregulated markets, the Free Market and Alternext, were created in 2004 and 2006. They are considered as multilateral trading facility (MTF) since November 1, 2007. They are unregulated in the sense of European directives and Belgian financial law. Firms quoted on those markets have neither obligation to follow International Accounting Standards (IAS)/International Financial Reporting Standards (IFRS) rules nor Belgian Code of Governance.

The rules are made by Euronext Brussels and approved by the Financial Services and Markets Authority (FSMA).

On those markets, the admission conditions and the obligation are voluntary soft to allow firms to focus on business (Euronext, 2006). They can raise new capital and reach new investors without fulfilling the rules of regulated markets. So, the unregulated markets are essentially composed by SMEs.

The particularity which interested us the most is that there is no obligation of internet financial communication for firms quoted on unregulated markets.

Pourtier (2004) explained that by defining what is required, we define by default what is voluntary. Given that no disclosure of financial information on the internet is required, any internet financial communication from listed companies on unregulated markets results from a voluntary effort. From then on, in the absence of obligation of communication, are companies quoted on these markets proactive regarding financial disclosure on their websites?

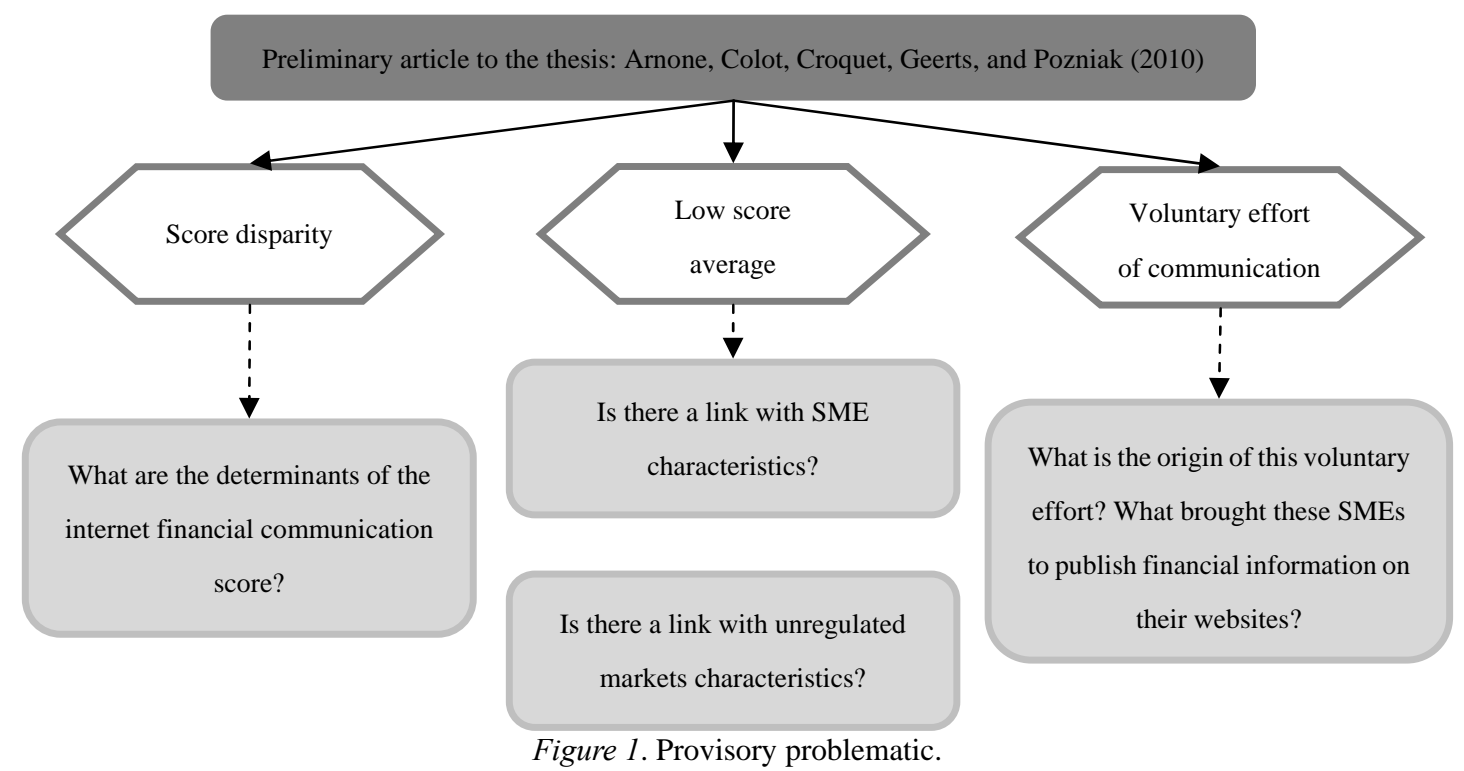

The first research that studied this question was Arnone et al. (2010). Their work and their results raise new research questions which are the start of our researches.

First, Arnone et al. (2010) found different levels of internet financial communication among the firms they observed. What element could explain this score disparity? What are the determinants of internet financial communication score? 
Then, they found that the mean communication score is quite low. Is it a general observation that can be made for all SMEs? Is there a link between SME characteristics and the level of internet financial communication? Or maybe is it the case for all firms quoted on unregulated markets, even outside Brussels? Is there a link between unregulated markets characteristics and the level of internet financial communication?

Finally, Arnone et al. (2010) underlined the voluntary effort of communication done by those firms. What is the origin of this voluntary effort? What brings those SMEs to publish financial information on their websites?

Those questions, rose from the exploratory study of Arnone et al. (2010), are the starting point of our researches and establish the provisory problematic of our thesis (see Figure 1 above).

\section{Methodological Approaches}

In this section, we expose the different methodologies used in our thesis to answer the questions presented before (see Figure 1). But before that, we explain how our study field was in evolution among our different researches.

\section{Study Field in Evolution}

Through papers of this thesis dedicated to internet financial communication of SMEs quoted on unregulated markets of Brussels, the field in the study is evolutionary.

Article No. 1 (Pozniak, 2010) was interested in companies quoted on unregulated markets of Brussels in 2009.

Article No. 2 (Pozniak \& Croquet, 2011) compared companies quoted on unregulated markets of Brussels with unquoted SMEs.

In the framework of Article No. 3 (Pozniak \& Guillemette, 2013), we met 10 managers of SMEs quoted on the Free Market of Brussels.

Analyses relative to Article No. 4 (Pozniak, 2013) were made in April 2012 and aimed at comparing companies quoted on unregulated markets of Brussels and Paris.

This study field in evolution is presented in Table 1.

Table 1

Study Field in Evolution

\begin{tabular}{lllll}
\hline Study field & Paper No. 1 & Paper No. 2 & Paper No. 3 & Paper No. 4 \\
\hline Analyses of websites & February 2009 & November 2009 & $2009-2012$ & April 2012 \\
Financial data & 2007 & 2008 & No & 2010 \\
Composition of sample & & & & 23 \\
Listed on the Free Market of Brussels & 28 & 26 & 10 & 11 \\
Listed on Alternext Brussels & 9 & 9 & & 23 \\
Unlisted SMEs & & 35 & & 11 \\
Listed on the Free Market of Paris & & & 10 & 68 \\
Listed on Alternext Paris & 37 & 70 & & \\
Number of firms studied & & & & \\
\hline
\end{tabular}

The number of companies in the study evolved from an article to the other one for two reasons: 
(1) On one hand, because the research objectives sometimes required widening the sample of companies in the study. It is the case in Article No. 2 (Pozniak \& Croquet, 2011) when unquoted SMEs were added and in Article No. 4 (Pozniak, 2013) when companies quoted on unregulated markets of Paris were added;

(2) On the other hand, there were new initial public offerings (IPOs), bankruptcies, and some companies left the quotation.

The various methodologies used in our four papers are summarized in Table 2 and developed below.

Table 2

Methodologies of Each Paper

\begin{tabular}{|l|l|l|l|l|}
\hline & Paper No. 1 & Paper No. 2 & Paper No. 3 & Paper No. 4 \\
\hline Approach & Quantitative & Quantitative & Qualitative & Quantitative \\
\hline Methodology & $\begin{array}{l}\text { Content analysis } \\
\text { Linear regression }\end{array}$ & $\begin{array}{l}\text { Paired sample } \\
\text { Content analysis } \\
\text { Linear regression }\end{array}$ & Interviews & $\begin{array}{l}\text { Paired sample } \\
\text { Content analysis } \\
\text { Linear regression }\end{array}$ \\
\hline Tools & Stata 10.1 & $\begin{array}{l}\text { Statistical Package for } \\
\text { Social Sciences (SPSS) } \\
\text { Stata 10.1 }\end{array}$ & Weft QDA & Stata 10.1 \\
\hline
\end{tabular}

\section{Content Analysis of Websites and Scoring}

Some academic papers studied the internet financial disclosure and listed the items that should appear on a firm's website (Allam \& Lymer, 2003; Oyelere, Laswad, \& Fisher, 2003; Xiao, Yang, \& Chow, 2004; Gowthorpe, 2004; Khadaroo, 2005; Lybaert, 2002; Pervan, 2006; Euronext, 2006; Dutta \& Bose, 2007; Abdelsalam, Bryant, \& Street, 2007; Oyelere \& Mohamed, 2007; Léger, 2008; Barredy \& Darras, 2008; Gabteni, 2011).

Thanks to those studies, we built our own analysis grid of websites, shown in Table 3.

Table 3

Analysis Grid of Websites
\begin{tabular}{|l|l|}
\hline Communication effort \\
\hline Firm's profile \\
\hline 1 & History \\
\hline 2 & Activities \\
\hline 3 & Strategy \\
\hline 4 & President's words \\
\hline 5 & Contact \\
\hline 6 & Market share \\
\hline 7 & Position regards to competitors \\
\hline Website’s ergonomy \\
\hline 8 & “Investors” (on the first page) \\
\hline 9 & “Press” or “news” (on the first page) \\
\hline 10 & Several language versions of the website \\
\hline 11 & Date of last changes on the website \\
\hline 12 & Help tools \\
\hline 13 & Search engine \\
\hline 14 & Roadshow video \\
\hline 15 & Joining a periodic letter \\
\hline 16 & Get the press release by mail \\
\hline Communication effort score \\
\hline
\end{tabular}


(Table 3 continued)

\begin{tabular}{|c|c|}
\hline \multicolumn{2}{|c|}{ Financial communication } \\
\hline 1 & Annual reports (for this year) \\
\hline 2 & Annual account (for this year) \\
\hline 3 & Audit report (for this year) \\
\hline 4 & Intermediate results (for this year) \\
\hline 5 & Management reports (for this year) \\
\hline 6 & Annual reports (for previous year) \\
\hline 7 & Annual account (for previous year) \\
\hline 8 & Audit report (for previous year) \\
\hline 9 & Intermediate results (for previous year) \\
\hline 10 & Management reports (for previous year) \\
\hline 11 & Prospectus of IPO \\
\hline 12 & Financial ratios or main key figures \\
\hline 13 & Board of directors reports \\
\hline 14 & General assembly reports \\
\hline 15 & Explanation about data \\
\hline 16 & Financial analysts reports \\
\hline 17 & Specific webpage for investors \\
\hline 18 & Link to Euronext's website \\
\hline 19 & Current share price \\
\hline 20 & History of share price \\
\hline 21 & Current dividend \\
\hline 22 & Previous dividends \\
\hline 23 & Shareholder structure \\
\hline 24 & Number of shares \\
\hline 25 & Organization chart \\
\hline 26 & Corporate governance \\
\hline 27 & Letter to shareholders \\
\hline 28 & Specific contact for investors \\
\hline 29 & Shareholder forum \\
\hline 30 & FAQ \\
\hline 31 & Shareholders' schedule \\
\hline 32 & Shareholders' guide \\
\hline 33 & Shareholders' rights \\
\hline 34 & Press release \\
\hline 35 & Press review \\
\hline \multicolumn{2}{|c|}{ Financial communication score } \\
\hline \multicolumn{2}{|c|}{ Total communication score } \\
\hline
\end{tabular}

For every item of the analysis grid available on a firm's website, a point is given. A communication score for every firm is obtained.

Many researches use this methodology (Allam \& Lymer, 2003; Oyelere et al., 2003; Xiao et al., 2004; Gowthorpe, 2004; Khadaroo, 2005; Lybaert, 2002; Abdelsalam et al., 2007; Oyelere \& Mohamed, 2007; Gabteni, 2011).

The evaluation of the communication level is often done by this scoring technique (Larran \& Giner, 2002). Indeed, the quantity of items available on a website is quite a good measure of disclosure effort (Branco \& Rodrigues, 2006). 
In several papers, items are not weighted to avoid subjectivity issues (Debreceny \& Rahman, 2005; Khadaroo, 2005; Paturel, Matoussi, \& Jouini, 2006; Abdelsalam et al., 2007; Jouini, 2007; Gabteni, 2011).

By the way, Chow and Wong-Boren (1987) demonstrated that same results are obtained with or without weighting the items when there are many items in the analysis grid.

\section{Linear Regression}

In some scientific papers (Debreceny \& Rahman, 2005; Paturel et al., 2006; Ben Rhouma \& Cormier, 2007; Jouini, 2007), the communication score is regressed according to explanatory variables in order to highlight the determinants of this score.

The model tested took on the following shape:

$$
\begin{gathered}
\text { Communication score }=\dot{\alpha}+\beta_{1}(\text { size })+\beta_{2}(\text { level of debts })+\beta_{3}(\text { performance }) \\
+\beta_{4}(\text { dispersion of capital })+\beta_{5}(\text { IT sector })
\end{gathered}
$$

We built some hypotheses and highlighted the independent variables thanks to a literature review about the determinants of internet financial disclosure (Craven \& Marston, 1999; Skaife, Johnstone, \& Warfield, 1999; Ho \& Wong, 2001; Larran \& Giner, 2002; Bonson \& Escobar, 2002; Debreceny, Gray, \& Rahman, 2002; Ettredge, Richardson, \& Scholz, 2002; Marston, 2003; Oyelere et al., 2003; Rodriguez \& Menezes, 2003; Xiao et al., 2004; Mendes-Da-Silva \& Christensen, 2004; Laswad, Fisher, \& Oyelere, 2005; Debreceny \& Rahman, 2005; Paturel et al., 2006; Bollen, Hassink, \& Bozic, 2006; Andrikopoulos \& Diakidis, 2007; Almilia, 2009a; 2009b; Oxibar, 2010).

Table 4 describes how the independent variables are measured.

Table 4

Measure of Independent Variables

\begin{tabular}{|l|l|}
\hline Variable & Measure \\
\hline Size & Log total assets \\
\hline Level of debts & Total debts/total assets \\
\hline Performance & Return on equity (ROE) and return on assets (ROA) \\
\hline Dispersion of capital & Free float \\
\hline IT sector & $1=$ IT; $0=$ other \\
\hline
\end{tabular}

\section{Paired Sample}

The paired sample technique (Caby, 1994; Thietart, 2003; Bughin \& Colot, 2008; Evrard, Pras, \& Roux, 2009; Malhotra, Birks, \& Wills, 2012) was used in Paper No. 2 where unlisted SMEs were added to our listed SMEs and in Paper No. 4 where companies listed in Paris were added to our Belgian firms.

The aim of this paired sample methodology is to match similar sample with regard to certain characteristics (in our case, the size and the sector). By doing this, we try to guarantee that the observed effect comes from the studied variable (the listing status in Paper No. 2 and the market place in Paper No. 4) instead of the difference of composition of samples. We check the structure of samples to obtain samples presenting identical structures. From then on, the errors due to the differences of composition of the groups are reduced (Thietart, 2003).

To construct a paired sample, we first look at the complete ICB Sector Code (Level 4). Then, we look at the size, approached by the total amount of assets. A variation of $20 \%$ is accepted. If there is no match for the size criteria, we look at a lower level of ICB sector. The turnover and the capitalization are also observed. 


\section{Interviews}

In Paper No. 3, we used a qualitative approach and we led interviews with 10 managers of firms listed on the Free Market of Brussels.

The qualitative approach is indicated when we want to understand a phenomenon (Miles \& Huberman, 2003; Paillé, 2007; Evrard et al., 2009). The epistemological positioning of qualitative research is that we can only study a human phenomenon by meeting the persons who live this phenomenon (Dilthey, 1942; Weber, 1949; Blumer, 1969; Husserl, 1977; Schutz, 1987). Furthermore, we can only have access to what they feel and what sense they give to an event by listening to what they say. So, the qualitative research favors the collection of speech data, because it aims at having access to the real-life experience of people and what they say about that (Blanchet \& Gotman, 2007). In other words, in qualitative research, the researcher tries to get data about people's perception from the inside (Miles \& Huberman, 2003).

By meeting managers and listening to their speech, we want to understand how they live the internet financial disclosure in their listed firms.

We made interviews (Kaufmann, 1996; Gavard-Perret, Gotteland, Haon, \& Jolibert, 2008; Savoie-Zajc, 2009) and we analyzed them referring to the principle of thematic analysis (Paillé \& Mucchielli, 2008; Corbin $\&$ Strauss, 2008). It means that we did not analyze the speech itself but the real-life experience of managers.

Derèze (2009) explained that interviews are indicated to talk about questions connected to the senses that actors give to the events or their actions, their representations, their values, or their practices.

Demazière and Dubar (2007) talked about three different postures according to the place which is granted to the words of the interviewees. The illustrative posture allows the author to select the extracts which will come to support his words. The restitutive posture attributes major importance for the words of the interviewees and writes them in the paper. The analytical posture, in which we are, aims at the production of sense.

\section{GT as a General Approach}

In this section, we demonstrate how GT was the general methodology of our thesis by papers and then, we present GT's characteristics and its wealth.

\section{GT as a General Methodology of a Papers Thesis}

The starting point of our thesis is an exploratory study led with other colleagues (Arnone et al., 2010). Literature review helped us to build our analysis grid of websites but no hypotheses were put. We were in an exploratory perspective and we let the data talk. This research was so in a GT epistemological view as “Grounded theory studies usually begin with questions about 'What's going on here?'. This is an appropriate method for the researcher who wants to learn from the participants and to understand a process or a situation" (Morse \& Richards, 2002, p. 55).

Built in 1967 by Glaser and Strauss (1967), in reaction to positivism and supremacies of deductive approaches (Evrard et al., 2009), GT is fundamentally inductive: That is the immersion in field's data which are the starting point of a research, not what other researchers found (Luckerhoff \& Guillemette, 2012).

In opposition to a deductive approach, which starts from existing theories and aims at checking hypotheses, GT does not force the data to fit in a theoretical framework; it is the data which bring a theory (Guillemette, 2006).

Results of preliminary article (Arnone et al., 2010) and its discoveries about internet financial communication raised new questions. In a rather natural way, we tried to answer it by means of a deductive 
approach. Hypotheses about internet financial disclosure's determinants were made and tested in companies quoted on unregulated markets of Brussels.

The second paper aimed at a deepening of the results obtained in Paper No. 1. Unquoted companies were added to the sample. The hypotheses made in Paper No. 1 were again tested, whereas a hypothesis relative to the quotation was added.

In Paper No. 3, we wanted to understand more in depth the manager's point of view. So, we choose a qualitative approach.

So, in an intuitive way, an article leads us to the following one. Article No. 3 raised the dysfunctions of the Free Market of Brussels and the debate which it arouses within the managers we met. Article No. 4 tried to compare the internet financial communication level between firms quoted in Brussels and Paris. We had the intuition that the Belgian companies, dissatisfied with their quotation, will be less inclined to make voluntary efforts of financial communication on their websites.

\section{Characteristics of GT}

A provisory problematic. In GT, a provisory problematic is drawn at the start of the research to put the boundaries of this research. The general problematic will evolve along the different researches and the final version will show up at the end of the study (Guillemette, 2006; Evrard et al., 2009; Guillemette \& Luckerhoff, 2009; Luckerhoff \& Guillemette, 2012; Plouffe \& Guillemette, 2012).

In our study, every paper raised new research questions that were answered in the next paper. So, the general problematic of our study was iterative. The problematic presented in Figure 1 was provisory. It evolved with each paper and the final problematic was defined at the end of the whole study.

So, our general study is inductive and fills this characteristic of GT: Problematic and research subject are first provisory and evolve along the different researches. Even if a problematic is defined at the start of the research, it evolves with elements discovered on the ground of the study (Willig, 2001). Instead of a precise problematic, the researcher identifies the parameters of the phenomenon studied (Strauss \& Corbin, 1998). "The research object is defined more like a ground to explore than like a research question” (Guillemette, 2006, p. 37).

General inductive approach. In GT, the general way to travel from a research to the next one is fundamentally inductive. Even if three papers of our thesis mobilize a quantitative method and a deductive approach, it is not against GT's principle. There can be verification of hypothesis and deduction phases in an inductive methodological travel.

As Holloway and Wheeler (2002, p. 155) said:

Strauss (1987) sees the processes of induction, deduction, and verification as essential in grounded theory. The approach is both inductive and deductive. Grounded theory does not start with a hypothesis though researchers might have "hunches". After collecting the initial data, however, relationships are established and provisional hypotheses conceived. These are verified by checking them out against further data.

The book of Glaser and Strauss (1967) presented GT in opposition to a deductive approach but they did not reject any deduction phases of hypothesis. Laperrière (1997, p. 311) explained that, "GT rejects building concepts and hypothesis before exploring the ground. Hypotheses and concepts must be verified on the ground along the research". In a deductive approach, hypotheses are built thanks to a literature review. "Grounded theory is for generating concepts problems and hypotheses, not for verifying 'received' problems and the validity of 'received' concepts” (Glaser, 1995, p. 10). 
Our approach fills this philosophy of research. The starting point of our thesis is an exploratory research led with the collaboration of colleagues (Arnone et al., 2010) on a new ground never studied before: the Free Market of Brussels. The literature review helped us to build our analysis grid of websites, but no research hypothesis was made. In an exploratory approach, we let the data talk; we do not force them to fill in a theoretical framework (Guillemette, 2006). So, this research was in GT, because "Grounded theory studies usually begin with questions about 'What's going on here?'. This is an appropriate method for the researcher who wants to learn from the participants and to understand a process or a situation” (Morse \& Richards, 2002, p. 55).

GT was built in 1967 by Glaser and Strauss (1967) in reaction to positivism and deductive approaches (Evrard et al., 2009). This general approach is fundamentally inductive: The start of the research is the study of data and ground, not the study of what was done before by other researchers (Luckerhoff \& Guillemette, 2012).

The results of this exploratory study (Arnone et al., 2010) raise several new questions. At the first step, we use a deductive approach to answer the question of communication's determinants and we write down some hypotheses which were tested later.

The second paper tries to deal with the first paper's results more in depth. We add unlisted firms and compare them with listed firms. We also write down hypotheses on communication's determinants and add a variable measuring the listing status.

After the two papers using a deductive approach, we feel the need to understand more in depth the phenomenon studied and to follow an inductive approach. A feeling about the link between manager's opinion and what we found on a company's website brings us to meet managers of the firms quoted on unregulated markets and to explore more in depth the phenomenon.

The third paper and the meeting with managers put into light some problems about the listing status on the Free Market. In this spirit, the fourth paper aims at comparing financial information disclosure level between Brussels and Paris.

Methodological flexibility. Methodological flexibility is one of the main characteristics of GT. More linked to qualitative approaches, GT is not against quantitative data and their analysis. Building theories based on a quantitative approach is possible (Luckerhoff \& Guillemette, 2012).

The founding book of Glaser and Strauss (1967) about GT has already talked about collecting quantitative and qualitative data in the same research project.

In GT, the research design can have induction and deduction phases and qualitative and quantitative methodologies can be used. Complementarity among those approaches is recommended by many research books (Malhotra, Décaudin, \& Bouguerra, 2004; Evrard et al., 2009; Gauthy-Sinéchal \& Vandercammen, 2010; Baines, Fill, \& Page, 2012; Lendrevie \& Lévy, 2012; Malhotra et al., 2012).

At the preliminary step of a research project, it is often a qualitative approach that is used. It is what we did with our preliminary study (Arnone et al., 2010). Exploratory studies are led when we know few things about the subject and we want to discover the general question linked to it (Baines et al., 2012). Those studies aim at highlighting the complexity of a subject and showing its different aspects (Lendrevie \& Lévy, 2012). They help us to understand the subject, prepare more in-depth studies, and build hypothesis which will be validated with a quantitative study.

Qualitative approach comes usually before quantitative studies, but it is not an obligation. Qualitative approach can be done to understand more in depth a subject studied before (Gauthy-Sinéchal \& Vandercammen, 2010; Cooper \& Schindler, 2006; Malhotra et al., 2004). 
It is the case with our third research. After two quantitative researches, we choose a qualitative approach to understand the real life of listed firms' managers and how they see the internet financial disclosure on an unregulated market.

Every research of our thesis uses the most appropriate methodology to answer the research question.

Researches 1, 2, and 3 use a quantitative approach, preconized when we want to measure, explain, and test theories (Cooper \& Schindler, 2006). First of all, we use the content analysis of websites to evaluate the level of internet financial disclosure and get a communication score. Then, we use linear regression to highlight the explanatory variables of this score (Debreceny \& Rahman, 2005; Paturel et al., 2006; Ben Rhouma \& Cormier, 2007; Jouini, 2007).

Furthermore, Researches 2 and 4 use the paired sample technique (Thietart, 2003; Evrard et al., 2009; Malhotra et al., 2012; Caby, 1994; Bughin \& Colot, 2008).

The third research uses a qualitative approach preconized when we want to understand the living situation of people (Paillé, 2007).

Up to our four researches, three of them use quantitative methodologies and follow a deductive approach. One research is fundamentally inductive and uses a qualitative methodology.

Sensitizing concepts. Strauss and Corbin (1998) said that a GT researcher has to be able to give sense to the data, overcome the first impression, and discover what is hidden. They defined this theoretical sensitiveness as a theoretical point of view with which data are perceived and interpreted.

Guillemette and Luckerhoff (2009) talked about "theoretical glasses, instrument of reading with which they dive into the empirical data to let appear an analysis". These theoretical glasses are also called sensitizing concepts (Blumer, 1969; Glaser \& Strauss, 1967; Glaser, 1978; 2005; Strauss, 1987; Van den Hoonaard, 1997). They favored the clear-sightedness of the researcher and helped him to identify what appears from data (Charmaz, 2004).

In this respect, in our thesis, a chapter dedicated to the sensitizing concepts relative to internet financial communication was written before presenting the thesis papers.

\section{GT's Wealth}

GT is very rich in many ways. First of all, by choosing an inductive travel among the different researches, we can capitalize on made studies to adjust and enrich the following researches. For example, we can talk about our analysis grid of websites and our research hypotheses on determinants which evolve in every paper.

Then, by using quantitative and qualitative approaches, as advised by GT, we get very complementary and rich results.

Finally, GT does not force data to fill in a theoretical framework, which allows unexpected results to show up. In our case, for example, we learn that the Free Market's managers are disappointed about the listing status and that they see it as a negative element for their communication effort.

By the way, as underlined by Luckerhoff and Guillemette (2012, p. 132), "In GT, the inductive approach can lead to many different interesting problematic. The researcher has to make choices and decide which leads follow or not if it's too far from the work already done”. Different questions rose from our researches but too far from our mean problematic were not developed in our thesis. Those leads demonstrate that GT is rich and raise so many new ways of study. 


\section{Conclusions}

The aim of this paper was, first, to present the various methodologies used to study internet financial communication and, second, to demonstrate how GT appeared to be the general methodology of a thesis by papers.

When articles of the thesis were ended and when we wanted to make a return not on the used methods, but on the general approach, in particular in the passages from an article to the other one, we discovered that intuitively, we had adopted an inductive approach by following the general instructions of GT.

Four articles of our thesis in economics and management sciences use alternately the qualitative and quantitative methodologies, according to the research questions. It is at the end of the research process that GT showed itself as a general methodology of our thesis.

At the first step, our scientific approach was exploratory. We explored a virgin ground of any analysis: unregulated markets of Euronext Brussels, and we tried to discover the level of financial communication on the websites of these companies.

Then, in a relatively natural way in economics and management sciences, we opted for a deductive approach and tried to identify the determinants of this level of investor financial communication on the internet.

Finally, a qualitative approach was adopted to understand in depth the phenomenon in the study. The emergence of GT as a general methodology of our thesis appeared only at the end of the research process. It is the general methodological travel which is in GT. Intuitively, we followed an inductive approach: Every article had for vocation to try to answer the questions raised by the previous article.

\section{References}

Abdelsalam, O. H., Bryant, S. M., \& Street, D. L. (2007). An examination of the comprehensiveness of corporate internet reporting provided by London-listed companies. Journal of International Accounting Research, 6(2), 1-33.

Allam, A., \& Lymer, A. (2003). Developments in internet financial reporting: Review and analysis across five developed countries. International Journal of Digital Accounting Research, 3(6), 165-199.

Almilia, L. (2009a). An empirical study of factors influencing internet financial and sustainability reporting in Indonesia Stock Exchange. Retrieved from http://www.afaanz.org/openconf/2009/modules/request.php?module=oc_program\&action=view.php\&id=158

Almilia, L. (2009b). Determining factors of internet financial reporting in Indonesia. Accounting and Taxation, 1(1), 87-99.

Andrikopoulos, A., \& Diakidis, N. (2007). Financial reporting practices on the internet: The case of companies listed in the Cyprus Stock Exchange. Working Paper, p. 22.

Arnone, L., Colot, O., Croquet, M., Geerts, A., \& Pozniak, L. (2010). Internet comme vecteur de communication financière: Une analyse des entreprises du Marché Libre. La Revue des Sciences de Gestion, Direction et Gestion, 242, 49-56.

Baines, P., Fill, C., \& Page, K. (2012). Le Marketing. Des fondamentaux à la pratique contemporaine (1st ed., p. 775). Bruxelles: De Boeck.

Barredy, C., \& Darras, N. (2008). L'utilisation d'internet dans la communication auprès des actionnaires minoritaires dans les entreprises familiales cotées. Journal des Entreprises Familiales, 1(1), 41-68.

Ben Rhouma, A., \& Cormier, D. (2007). Déterminants de la communication sociale et environnementale des enterprises françaises. 28ème Congrès de l'Association Francophone de Comptabilité “Comptabilité et Environnement”, IAE Poitiers.

Blanchet, A., \& Gotman, A. (2007). L'enquête et ses méthodes: L'entretien (2nd ed.). Paris: Armand Colin.

Blumer, H. (1969). Symbolic interactionism: Perspective and method. Englewood Cliffs, NJ: Prentice Hall.

Bollen, L., Hassink, H., \& Bozic, G. (2006). Measuring and explaining the quality of internet investor relations activities: A multinational empirical analysis. International Journal of Accounting Information Systems, 7, 273-298.

Bonson, E., \& Escobar, T. (2002). A survey on voluntary disclosure on the internet: Empirical evidence from 300 European Union companies. International Journal of Digital Accounting Research, 2(1), 27-51.

Branco, M. C., \& Rodrigues, L. L. (2006). Communication of corporate social responsibility by Portuguese banks: A legitimacy theory perspective. Corporate Communications: An International Journal, 11(3), 232-248. 
Bughin, C., \& Colot, O. (2008). La performance des PME familiales belges: Une étude empirique. Revue Française de Gestion, 34(186), 1-17.

Caby, J. (1994). Motivations etefficacité des offers publiques d'achat et d'échange en France de 1970 à 1990 (Thèse de doctorat, Université de Nancy II, p. 676).

Charmaz, K. (2004). Grounded theory. In S. N. Hesse-Biber \& P. Leavy (Eds.), Approaches to qualitative research (pp. 496-521). New York, NY: Oxford University Press.

Chow, C. W., \& Wong-Boren, A. (1987). Voluntary financial disclosure by Mexican corporations. The Accounting Review, 62(3), 533-541.

Cooper, D. R., \& Schindler, P. S. (2006). Business research methods (9th ed., p. 744). New York, NY: McGraw-Hill International Edition.

Corbin, J., \& Strauss, A. L. (2008). Basics of qualitative research (3rd ed.). Thousand Oaks, CA: Sage Publications.

Craven, B. M., \& Marston, C. L. (1999). Financial reporting on the internet by leading UK companies. European Accounting Review, 8(2), 321-333.

Debreceny, R., \& Rahman, A. (2005). Firm-specific determinants of continuous corporate disclosures. The International Journal of Accounting, 40(3), 249-278.

Debreceny, R., Gray, G., \& Rahman, A. (2002). The determinants of internet financial reporting. Journal of Accounting and Public Policy, 21(4-5), 371-394.

Demazière, D., \& Dubar, C. (2007). Analyser les entretiens biographiques. L'exemple de récits d'insertion (2nd ed., p. 350). Canada: Les presses de l’Université de Laval.

Derèze, G. (2009). Méthodes empiriques de recherché en communication (1st ed., p. 256). Bruxelles: Editions De Boeck Université.

Dilthey, W. (1942). Introduction à l'étude des sciences humaines. Paris: Presses Universitaires de France.

Dutta, P., \& Bose, S. (2007). Web-based corporate reporting in Bangladesh: An exploratory study. The Cost and Management, 35(6), 29-45.

Ettredge, M., Richardson, V., \& Scholz, S. (2002). Dissemination of information for investors at corporate web sites. Journal of Accounting and Public Policy, 21(4-5), 357-369.

Euronext. (2006). Recommandations pour un parcours boursier réussi sur le Marché Libre (p. 4). Retrieved from http://www.euronext.com/fic/000/010/800/108002.pdf

Evrard, Y., Pras, B., \& Roux, E. (2009). Market. Fondements et méthodes des recherches en marketing (4th ed., p. 703). Paris: DUNOD.

Gabteni, H. (2011). Construction d'un score de publication volontaire entendu comme une mesure de la communication financière en période pré/post IFRS (p. 39). Comptabilités, économie et société, Montpellier, France.

Gauthy-Sinéchal, M., \& Vandercammen, M. (2010). Etudes de marchés. Méthodesetoutils (3rd ed., p. 462). Bruxelles: De Boeck.

Gavard-Perret, M. L., Gotteland, D., Haon, C., \& Jolibert, A. (2008). Méthodologie de la recherche: Réussir son mémoire.

Glaser, B. G. (1978). Theoretical sensitivity. Mill Valley, CA: Sociology Press.

Glaser, B. G. (1995). A look at grounded theory: 1984 to 1994. In B. G. Glaser (Ed.), Grounded theory: 1984-1994 (pp. 3-17). Mill Valley, CA: Sociology Press.

Glaser, B. G. (2005). The grounded theory perspective III: Theoretical coding. Mill Valley, CA: Sociology Press.

Glaser, B. G., \& Strauss, A. L. (1967). The discovery of grounded theory: Strategies for qualitative research. Chicago, IL: Aldine.

Gowthorpe, C. (2004). Asymmetrical dialogue? Corporate financial reporting via the internet. Corporate Communications, 9(4), 283-293.

Guillemette, F. (2006). L'approche de la Grounded Theory; pour innover? Recherches Qualitatives, 26(1), 32-50.

Guillemette, F., \& Luckerhoff, J. (2009). L’induction en méthodologie de la théorisation enracinée (MTE). Recherches Qualitatives, 28(2), 4-21.

Ho, S., \& Wong, K. (2001). A study of the relationship between corporate governance structures and the extent of voluntary disclosure. Journal of International Accounting, Auditing, and Taxation, 10(2), 139-156.

Holloway, I., \& Wheeler, S. (2002). Sampling. In I. Holloway \& S. Wheeler (Eds.), Qualitative research in nursing (2nd ed., pp. 122-131). Oxford: Blackwell.

Husserl, E. (1977). Phenomenological psychology. The Hague: Martinus Nijhoff.

Jouini, S. (2007). Les facteurs determinants et les caractéristiques de la stratégie des entreprises en matière de communication financière sur leur site Web. 28ème Congrès de l'Association Francophone de Comptabilité "Comptabilité et Environnement" IAE Poitiers. 
Kaufmann, J. C. (1996). L'entretien compréhensif. Paris: Nathan.

Khadaroo, I. (2005). Business reporting on the internet in Malaysia and Singapore: A comparative study. Corporate Communications: An International Journal, 10(1), 58-68.

Laperrière, A. (1997). La théorisation ancrée (grounded theory): Démarche analytique et comparaison avec d'autres approaches apparentées. In J. Poupart, J. P. Deslauriers, L. H. Groulx, A. Laperrière, R. Mayer, \& A. P. Pires (Eds.), La recherche qualitative: Enjeux épistémologiques et méthodologiques (pp. 309-340). Boucherville: G. Morin.

Larran, M., \& Giner, B. (2002). The use of the internet for corporate reporting by Spanish companies. International Journal of Digital Accounting Research, 2(1), 53-82.

Laswad, F., Fisher, R., \& Oyelere, P. (2005). Determinants of voluntary internet financial reporting by local government authorities. Journal of Accounting and Public Policy, 24(2), 101-121.

Léger, J. Y. (2008). La communication Financière (2nd ed., p. 278). Paris: DUNOD.

Lendrevie, J., \& Lévy, J. (2012). Mercator 2013. Théories et nouvelles pratiques du marketing (p. 1130). Paris: Dunod.

Luckerhoff, J., \& Guillemette, F. (2012). Description de la mise en ouvre de la MTE dans le cadre d'unerecherche en communication et en éducation. In J. Luckerhoff \& F. Guillemette (Eds.), Méthodologie de la théorisation enracinée: Fondements, procédures et usages (pp. 115-140). Québec: Presses de l’Université du Québec.

Lybaert, N. (2002). On-line financial reporting. An analysis of the Dutch listed firms. International Journal of Digital Accounting Research, 2(4), 195-234.

Malhotra, N. K., Birks, D. F., \& Wills, P. (2012). Marketing research: An applied approach (4th ed., p. 1037). Harlow: Pearson.

Malhotra, N. K., Décaudin, J. M., \& Bouguerra, A. (2004). Etudes marketing avec SPSS (4th ed., p. 664). Paris: Pearson.

Marston, C. (2003). Financial reporting on the internet by leading Japanese companies. Corporate Communications: An International Journal, 8(1), 23-34.

Mendes-Da-Silva, W., \& Christensen, T. (2004). Determinants of voluntary disclosure of financial information on the internet by Brazilian firms. Retrieved from http://papers.ssrn.com/sol3/papers.cfm?abstract_id=638082

Miles, M. B., \& Huberman, M. A. (2003). Analyse des données qualitatives (2nd ed., p. 626). Bruxelles: De Boeck.

Morse, J. M., \& Richards, L. (2002). Read me first for a user's guide to qualitative methods. Thousand Oaks, CA: Sage Publications.

Oxibar, B. (2010). Communication financière sur les sites internet des groupes cotés français. Crises et nouvelles problématiques de ma Valeur, Nice, France, p. 51.

Oyelere, P., \& Mohamed, E. (2007). Internet financial reporting in Oman. Global Journal of Business Research, 1(2), 45-54.

Oyelere, P., Laswad, F., \& Fisher, R. (2003). Determinants of internet financial reporting by New Zealand companies. Journal of International Financial Management and Accounting, 14(1), 26-63.

Paillé, P. (2007). La recherche qualitative. Une méthodologie de la proximité. In H. Dorvil (Ed.), Problèmes sociaux. Tome III. Théories et méthodologies de la recherche (pp. 409-443). Québec: Presses de l’Université du Québec.

Paillé, P., \& Mucchielli, A. (2008). L'analyse qualitative en sciences humaines et sociales (2nd ed.). Paris: Armand Colin.

Paturel, R., Matoussi, H., \& Jouini, S. (2006). Les motivations de la communication financière des enterprises françaises et britanniques à travers le web. 5ème Colloque International de la recherche en sciences de gestion, Hammamet, Tunisie, Mars.

Pervan, I. (2006). Voluntary financial reporting on the internet: Analysis of the practice of Croatian and Slovene listed joint stock companies. Financial Theory and Practice, 30(1), 1-27.

Plouffe, M. J., \& Guillemette, F. (2012). La MTE commeapport au développement de la recherche en arts. In J. Luckerhoff \& F. Guillemette (Eds.), Méthodologie de la théorisation enracinée: Fondements, procédures et usages (pp. 87-114). Québec: Presses de l’Université du Québec.

Pourtier, F. (2004). La publication d'informations financières volontaires: Un essai de synthèse. Cahiers électroniques du CRECCI, IAE, Cahier 08, No. ISRN IAE 33/CRECCI-2004-08-FR, p. 37.

Pozniak, L. (2010). Financial communication on the web: Evidence from Belgium. Accounting and Taxation, 2(1), 47-58.

Pozniak, L. (2013). Internet financial communication: Evidence from unregulated markets in Brussels and Paris. International Journal of Business and Finance Research, 7(5), 107-122.

Pozniak, L., \& Croquet, M. (2011). Analyse des déterminants de la communication financière sur le net. Le cas des Marchés non réglementés de la Bourse de Bruxelles. Journal of Small Business and Entrepreneurship, 24(3), 329-344.

Pozniak, L., \& Guillemette, F. (2013). Les dirigeants de PME et la communication financière sur internet. Revue Internationale PME. 
Rodriguez, L., \& Menezes, C. (2003). Financial reporting on the internet. The Portuguese case. RAE Electronica, 2 (2), 22.

Savoie-Zajc, L. (2009). L'entrevue semi-dirigée. In B. Gauthier (Ed.), Recherche sociale: De la problématique ŕ la collecte de données (5th ed., pp. 337-360). Québec: Presses de l’Université du Québec.

Schutz, A. (1987). Le chercheur et le quotidien. Phénoménologie des sciences sociales. Paris: Méridiens Klincksieck.

Skaife, H. A., Johnstone, K. M., \& Warfield, T. (1999). Corporate reporting on the internet. Accounting Horizons, 13(3), $241-257$.

Strauss, A. L. (1987). Qualitative analysis for social scientists. New York, NY: Cambridge University Press.

Strauss, A. L., \& Corbin, J. (1998). Basics of qualitative research (2nd ed.). Thousand Oaks, CA: Sage Publications.

Thietart, R. A. (2003). Méthodes de recherche en management (2nd ed., p. 537). Paris: Dunod.

Van den Hoonaard, W. C. (1997). Working with sensitizing concepts: Analytical field research. Thousand Oaks, CA: Sage Publications.

Weber, M. (1949). The methodology of the social sciences. New York, NY: Free Press.

Willig, C. (2001). Introducing qualitative research in psychology. Buckingham, UK: Open University Press.

Xiao, J., Yang, H., \& Chow, C. (2004). The determinants and characteristics of voluntary internet-based disclosures by listed Chinese companies. Journal of Accounting and Public Policy, 23(3), 191-225. 